\title{
MOÇAMBIQUE E SUAS PARTICULARIDADES: VIVÊNCIAS E OLHARES
}

\author{
MOZAMBIQUE AND ITS PARTICULARITIES: EXPERIENCES AND VIEWS
}

\section{RESUMO}

O texto em questão aborda a terceira missão de estudos, pesquisa, intercâmbio e mobilidade do Projeto "Práticas sociais e saberes de mulheres e homens e a produção do território rural no Distrito de Marracuene, em Moçambique: viabilidade das alternativas produtivas no mundo da sustentabilidade". Missão na qual ambos os autores deste artigo participaram na condição de doutorandos em Geografia, e estavam em sua primeira viagem ao continente africano. $O$ texto relata, na perspectiva dos autores, um olhar ao que nos assemelham, ou nos aproximam, mesmo que apresentado de forma tímida, ou interpretado superficialmente. Porém, buscamos destacar Moçambique e suas particularidades, utilizando nossa vivência e nossos olhares no tempo de convivência e aprendizado em que estivemos por lá. Dentre as principais similitudes, possivelmente a primeira a se destacar, é o fato de termos o Português como idioma oficial, e que apesar de falarmos o mesmo idioma, por vezes não falávamos a mesma "língua". As diferenças linguísticas tornaram-se evidentes e por diversas ocasiões precisávamos de alguma "tradução". Ademais, a maioria das pessoas domina no mínimo outra língua e/ou dialeto, tão ou mais falado, de modo que ao caminharmos pelas ruas de Maputo, nem parecia que estávamos em um país lusófono. Apesar de alguns contratempos provocados pelas diferenças linguísticas e culturais, a receptividade do povo moçambicano foi sempre um diferencial. Dentre tantos pontos que enriqueceram nossa experiência abordada no texto, destacamos também que ficamos alojados em um dos prédios da moradia estudantil da Universidade Eduardo Mondlane (UEM), o que aprofundou nossa imersão.

Palavras-chave: Moçambique. Experiência. Intercâmbio. Geografia. Práticas Sociais

\section{ABSTRACT}

The text in question addresses the third mission of studies, research, exchange and mobility of the Project "Social practices and knowledge of women and men and the production of rural territory in the Marracuene District, in Mozambique: viability of productive alternatives in the world of sustainability". Mission in which both authors of this article participated as PhD students in Geography, and were on their first trip to the African continent. The text reports, from the perspective of the authors, a look at what they resemble or approach us, even if presented in a timid way, or superficially interpreted. However, we seek to highlight Mozambique and its particularities, using our experience and our views in the time of coexistence and learning that we were there. Among the main similarities, possibly the first to stand out, is the fact that we have Portuguese as the official language, and that although we speak the same language, sometimes we did not speak the same "language". The linguistic differences became evident and on several occasions, we needed some "translation". In addition, most people at least speak at least one other language and / or dialect, so or more spoken, so that when walking through the streets of Maputo, it did not even seem like we were in a Portuguese-speaking country. Despite some setbacks caused by linguistic and cultural differences, the receptivity of the Mozambican people has always been a differential. Among so many points that enriched our experience covered in the text, we also highlight that we were housed in one of the buildings of the student housing at Eduardo Mondlane University (UEM), which deepened our immersion.

Keywords: Mozambique. Experience. Exchange; Geography. Social Practices.

\section{Amilton Luiz Novaes ${ }^{\text {a }}$ \\ Karoline Batista Gonçalves a \\ a Universidade Federal da Grande Dourados (UFGD), Dourados, MS, Brasil}

DOI: $10.12957 /$ geouerj.2020.53706

Correpondência: amiltonnovaes@ufgd.edu.br

Recebido em: 13 out 2019

Revisado em: 17 jan 2020

Aceito em: 19 mar 2020 


\section{INTRODUÇÃO}

Este artigo se propõe a relatar a terceira missão de estudos, pesquisas, intercâmbio e mobilidade, sendo uma etapa do Projeto "Práticas sociais e saberes de mulheres e homens e a produção do território rural no Distrito de Marracuene em Moçambique: viabilidade das alternativas produtivas no mundo da sustentabilidade". Nessa terceira missão fomos os dois autores desse texto, na condição de alunos de doutorado do Programa de Pós-Graduação em Geografia da Universidade Federal da Grande Dourados, e o coordenador do Projeto Prof. Edvaldo Cesar Moretti, que permaneceu apenas nos sete primeiros dias. 0 tempo total da missão foi de trinta e um dias, considerando o deslocamento, ocorridos entre 25/09/2015 e 25/10/2015.

Vale ressaltar que, essa era a primeira viagem de ambos os autores ao continente africano, ou seja, o primeiro contato com a cultura e os costumes africanos in loco. Porém, geralmente, ao aventarmos o tema África, abordamos principalmente aquilo que, pelo nosso olhar, nos assemelham. Ou seja, alguns aspectos que nos aproximam, sejam os traços da fisionomia ou as referências culturais. No entanto, muitas dessas características são apresentadas de forma muito tímida ou porque não afirmar, interpretadas superficialmente.

Moçambique é um país do continente africano, localizado na África Austral com características e elementos muito particulares, capaz de fascinar aqueles que se dispõem a viver uma experiência em suas terras. Territorialmente, o país tem sua estrutura organizada em províncias, distritos, postos administrativos, localidades e povoações. Sendo a cidade de Maputo sua capital, nosso principal destino. O distrito de Marracuene, onde parte de nossas atividades foram desenvolvidas, é um distrito próximo a capital, localizado na Província de Maputo. É interessante destacar que, a capital da Província de Maputo, é a cidade de Matola, sendo que a cidade de Maputo, capital nacional é também considerada uma província.

Apesar de claramente ser uma análise superficial dizer que temos semelhanças entre Brasil e Moçambique, algumas (mesmo que negativamente) de fato nos aproximam, e principalmente aqui me refiro ao idioma oficial, o português. Isto pois, ambos os países foram colônias de Portugal (por isso mencionamos o aspecto negativo da semelhança). Todavia, apesar de ser falado o mesmo idioma, por vezes não falávamos a mesma "língua". As diferenças linguísticas eram evidentes e por diversas ocasiões precisávamos de alguma "tradução".

Embora o idioma português seja o oficial, a maioria das pessoas domina no mínimo outra língua e/ou dialeto que foi ensinado por seus antepassados e que se mantêm viva na atualidade. Existe uma grande diversidade de línguas e dialetos presentes no país. De tantos idiomas, dialetos ou línguas faladas, ao caminharmos pelas ruas de Maputo, nem parecia que estávamos em um país lusófono. Além é claro, de que 
sempre ouvíamos diferentes expressões que até então eram desconhecidas. Vale destacar que, o idioma inglês também está muito presente, principalmente na cidade de Maputo, por diversas características, mas, com destaque por esta ser a capital e pela proximidade com a África do Sul.

Tais dialetos não eram ouvidos somente nas ruas, verificamos sua presença nas rádios, músicas, na arte, dentre outras coisas, ou seja, faziam parte do cotidiano das pessoas. De acordo com Timbane $(2014$, p. 04) em Moçambique é possível encontrar as seguintes línguas: kiswahili, kimwani, shimakonde, ciyao, emakhuwa, ekoti, elomwé, echuwabo, cinyanja, cisenga, cinyungwé, cisena, cishona, xitswa, xironga, xichangana, gitonga, cicopi, xiswati, xizulu. Muitas destas línguas são internacionais, ou seja, são faladas em outros países do continente africano. Diante disso, podemos pensar que as fronteiras políticas são diferentes das fronteiras linguísticas, pois essas eram faladas pelos africanos, moçambicanos e populações de países vizinhos, muitos anos antes da chegada dos colonizadores.

Sabemos é claro que os colonizadores utilizam o idioma como um meio de dominação dos povos que se encontravam nesse território, e além de menosprezar, muitas vezes buscavam extinguir as línguas africanas faladas na época. Em relação ao português que é falado em Moçambique Timbane (2014, p. 11) enfatiza que houve um processo de "nativização ou moçambilicalização" ${ }^{1}$ do português, oriundo de uma aprendizagem irregular por parte destes. Processo semelhante ao que vivenciamos no Brasil. Todavia, aos nossos ouvidos, percebemos que o português falado lá, se aproxima muito mais do português de Portugal do que o que é falado no Brasil.

Apesar de alguns contratempos provocados pelas diferenças linguísticas e culturais, a receptividade do povo moçambicano foi sempre um diferencial. Fomos recebidos institucionalmente pela Universidade Eduardo Mondlane (UEM), universidade parceira do projeto. Tratar da relação, vivência e experiência que tivemos com a UEM, merece um tópico à parte, porém, podemos adiantar que ficamos alojados em um dos prédios da moradia estudantil. Ao todo eram nove prédios, espalhados pela cidade e campus universitário, destinados a moradia dos estudantes, principalmente para aqueles que vinham de outras localidades.

Ficar instalado nesse prédio nos permitiu uma real e profunda imersão (já que foram poucos dias) em uma realidade mais próxima dos estudantes locais. Foi possível conhecer estudantes da UEM, de diversas áreas do conhecimento, mas também estudantes de outras localidades do Brasil (Minas Gerais, São Paulo, Bahia, Rio de Janeiro e até mesmo de Dourados, estes alunos do curso de Relações Internacionais também da (UFGD) e até de outros países (tal como México, Alemanha e Itália). Intercambistas que como nós estavam desenvolvendo projetos de pesquisa e, ou, mobilidade internacional.

\footnotetext{
${ }^{1}$ Termo utilizado pelo autor.
} 
Foi possível vivenciar o cotidiano estudantil do povo moçambicano, obviamente uma vivência temporária. Sem falar que devido aos valores financeiros que tínhamos disponíveis, somados à desvalorização da moeda local no câmbio, nossas condições econômicas eram certamente superiores à de todos os estudantes moçambicanos e de boa parte da população do país.

Contudo, enfrentamos alguns dos mesmos problemas sociais que acometiam a população em geral, tal como a constante interrupção no abastecimento de água (por diversos dias tivemos que reservar, ou comprar ${ }^{2}$, água para banho e higiene pessoal), a precariedade do transporte coletivo (nos deslocamos a pé em diversas ocasiões no trajeto entre alojamento e $U_{E M}^{3}$ ), o trânsito distinto para nós devido à utilização da mão inglesa e caótico pelo desrespeito às regras e as leis, ausência de água potável para consumo humano (não há saneamento básico em boa parte da cidade), coleta e destinação adequada dos resíduos deficitária (grande volume de lixo "jogado/espalhado" pela cidade), além dos cuidados com uma ameaça recorrente na cidade, a Malária, os crescentes casos de violência, dentre outras coisas.

Cabe destacar que nada disso tirou nosso encantamento com o país, a cidade e, principalmente, o povo moçambicano, que foram sempre muito receptivos e prestativos. Visando ilustrar alguns desses aspectos, apresentamos nas Figuras 1 e 2, imagens que retratam os principais meios de transporte na cidade de Maputo.

Figura 1. Meios de transporte individual, tuc tuc à esquerda e táxi à direita Fotos de Karolina Batista Gonçalves (2016).

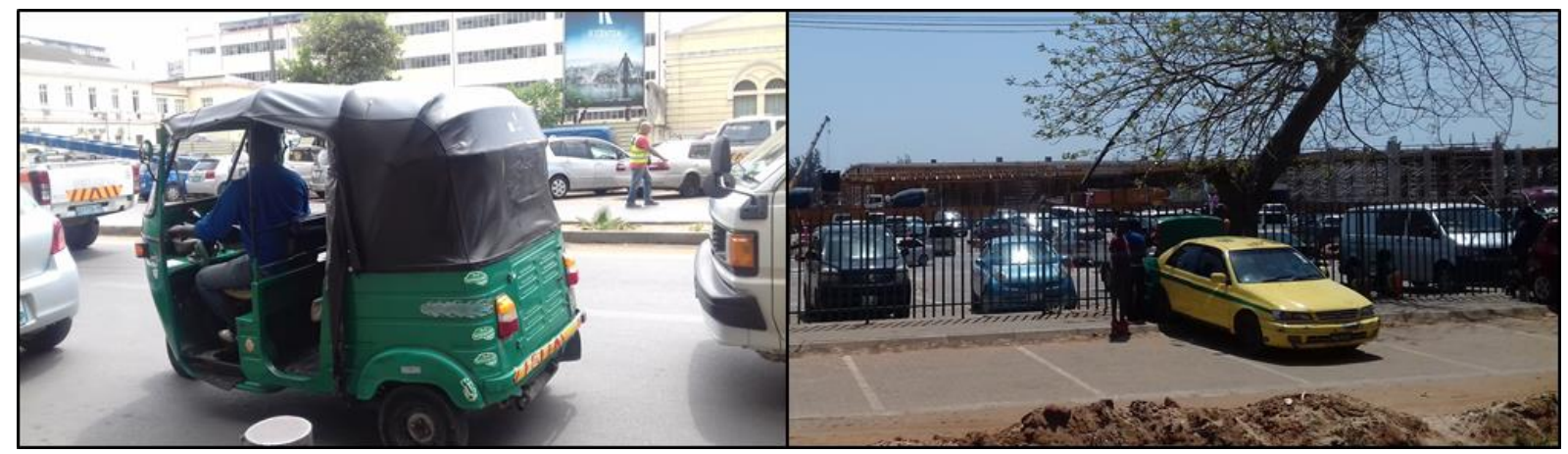

\footnotetext{
${ }^{2}$ A possibilidade de comprar água só foi possível devido ao nosso poder aquisitivo pelas razões já explicitadas. Pois, os moradores locais, por diversas vezes tinham que adequar sua rotina às disponibilidades do fornecimento de água, acarretando até mesmo em faltar aula, dentre outras coisas.

${ }^{3}$ Apesar de que em diversas ocasiões de desenvolvimento de atividades do projeto, principalmente fora do campus, tínhamos carro e motorista da universidade para nos levar.
} 
Figura 2. Exemplos de transporte coletivo - à esq. Vans e à dir. os chamados "My love"4 Fotos de Amilton Luiz Novaes (2016).

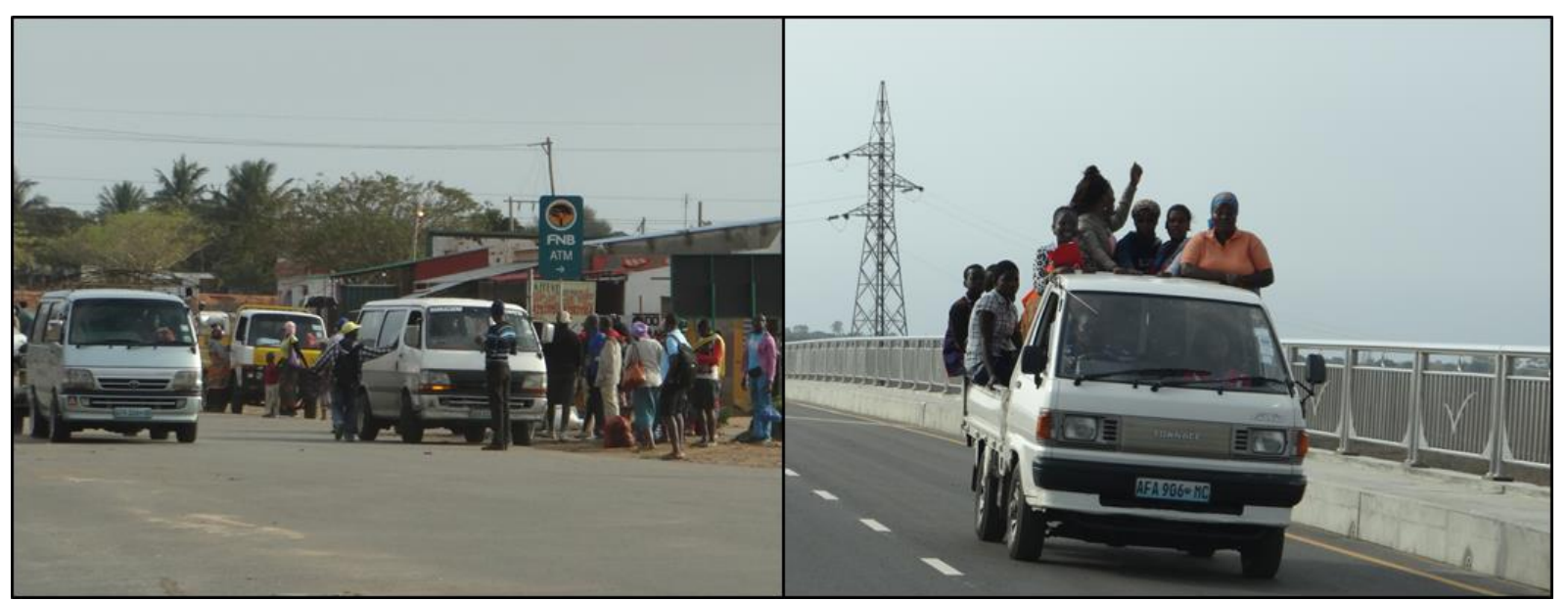

Ressalto que não há como comparar nossa (curta) estadia com o cotidiano dos estudantes locais, ou mesmo da população em geral, ainda mais nas condições que dispúnhamos. No entanto, nos permitiu ao menos que tivéssemos conhecimento dessa situação, contudo, um conhecimento mais humanizado e não só uma simples descrição das características de infraestrutura urbana ou das condições sociais. Ou seja, uma vivência, algo que seria possível apenas estando lá.

Neste artigo procuramos dividir o texto em tópicos que englobassem a quase totalidade dos assuntos referentes às nossas experiências, vivências, olhares (ou leituras) da cidade, sociedade, universidade, cultura, etc. Desta forma, no primeiro tópico apresentamos nossas impressões sobre a universidade, estrutura universitária, dentre outras características relacionadas à mesma, e relatando algumas de nossas atividades diretamente relacionadas a ela. Em outro tópico, iremos abordar nossa leitura das questões culturais, tais como arte, vestimentas, alimentação, e outros elementos da cultura moçambicana. Mais adiante, deixamos um tópico para abordar as questões mais de cunho econômico, do comércio e do trabalho. E por fim, trataremos também das questões relacionadas ao turismo local, apesar de ser algo extremamente complexo buscaremos demonstrar nossas impressões acerca do assunto.

\section{Universidade}

Preferimos deixar o assunto universidade em um tópico à parte, pois nossas atividades relacionadas à UEM foram, além de numerosas, bastante intensas. A nossa primeira atividade, já no dia seguinte em que

${ }^{4} \mathrm{O}$ "My Love" são pequenos caminhões com a carroceria aberta, utilizados no transporte coletivo, e leva esse nome, pois as pessoas precisam ir abraçadas (no estilo "My Love") para ficarem "firmes" em cima da carroceria. 
chegamos em Maputo, foi participar da IX Conferência Científica 2016, com o título: Investigação para o Desenvolvimento: Tendências, Desafios e Perspectivas, ocorrida nos dias 27 e 28 de setembro de 2016 . É importante destacar que já estava programado desde o convite para integrar a missão, a submissão e apresentação (se aprovado) de trabalho relacionado às nossas pesquisas no doutorado. Já se iniciava assim, o intercâmbio internacional de conhecimento.

Figura 3. Participantes da IX Conferência Científica 2016. Foto de autor desconhecido (2016).

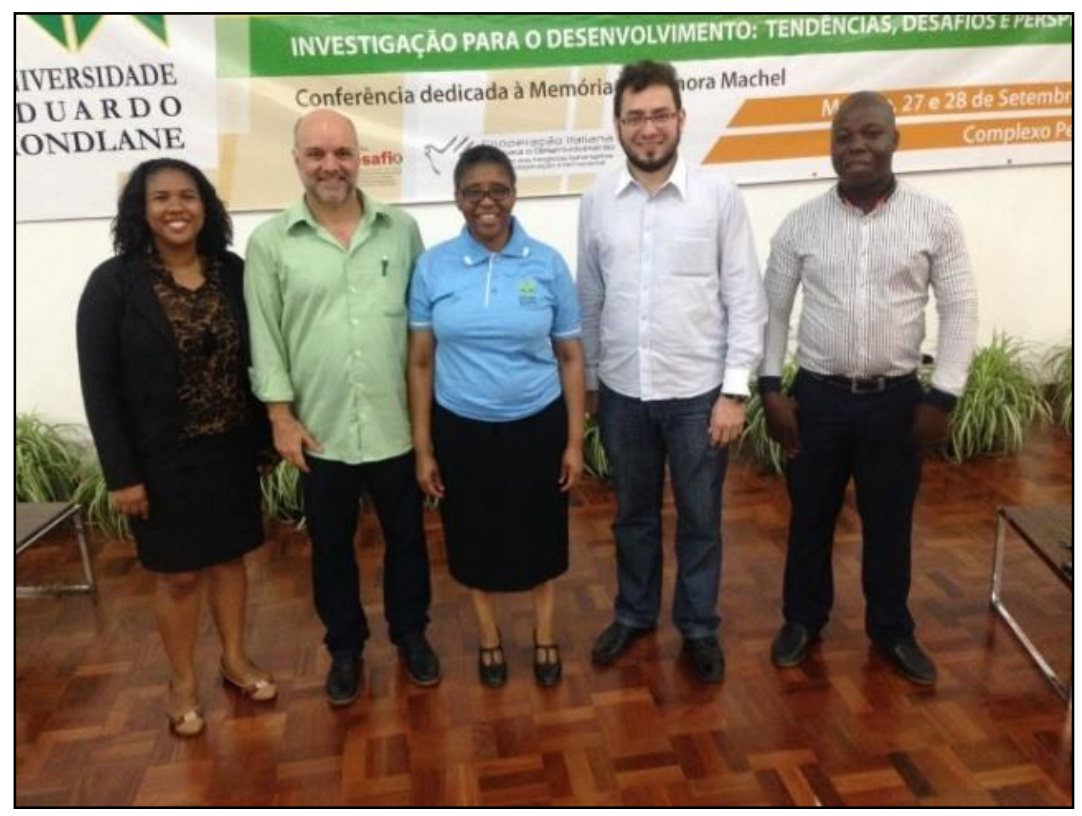

A experiência dessa participação foi bastante enriquecedora e podemos dizer também esclarecedora. Isto pois, apesar de pretendermos uma ciência universal e por mais que os assuntos abordados fossem próximos, ou semelhantes, à ambos os países, foi bastante desafiador apresentar trabalhos que tratavam de aspectos localizados especificamente no Brasil e na América do Sul, para um público interessado em discutir as questões africanas e/ou moçambicanas. Todavia, o debate foi profícuo e a imersão no contexto da produção e divulgação da ciência produzida em Moçambique, nos ajudou a compreender melhor a pesquisa e o ensino no contexto universitário de Moçambique.

Dentre diversas características que nos chamaram a atenção na estrutura universitária, destacamos as seguintes:

- Formalidade extrema: 
Há um excesso de formalismo em toda a universidade e em tudo que se faz por lá. Por exemplo, éramos chamados de doutor e doutora o tempo todo, e por quase todos. Quase todos, porque a estrutura hierárquica universitária é bastante formal além de rígida, sendo assim, aqueles que numa lógica hierárquica estivessem abaixo de nós deveriam (meio que obrigatoriamente) nos chamar de doutor e doutora.

Outra característica nesse mesmo sentido é que eles denominavam a todos como doutores, dando relevância e uma maior importância àqueles que possuíam uma formação universitária, porém diferenciavam os "doutores" conforme a titulação. Tínhamos doutores e Doutores (dr., doutor e Dr.), ou seja, conforme o título era "maior" o "doutor" também.

\section{- Universidade pública, gratuita e paga:}

Nos tempos atuais, volta a rondar as universidades públicas do Brasil a discussão sobre pagamentos de mensalidades, ou outros pagamentos. Uma das propostas atuais (mas não nova) é que quem "tiver condições" de pagar mensalidade deveria pagar e seria gratuita para quem não tiver. Para além da discussão de se isso seria adequado ou não (apesar de ferir por completo a constituição e descaracterizar a universidade pública gratuita de qualidade), temos que abordar que condições seriam essas e quem decidiria quais alunos teriam condições ou não.

Haja visto o exemplo da Universidade Eduardo Mondlane que segue uma lógica parecido com essa proposta no Brasil. Lá eles possuem cursos diurnos e noturno, denominados de diurno (que funcionam no horário de trabalho) e o pós laboral (que funciona após o horário de trabalho, esse seria o noturno). Os alunos dos cursos pós laboral pagam mensalidades, enquanto os demais alunos pagam "apenas" taxas (tal como taxa de matrícula).

A defesa a estes pagamentos é que os alunos que trabalham, e assim irão cursar no período noturno, "possuem condições" de pagar as mensalidades já que eles trabalham. Aqueles do curso diurno, já que não poderão trabalhar, pois estão estudando, não pagam mensalidades. Não avaliamos aqui se "certo ou errado", apenas é uma característica que a nós merece destaque, e vale a reflexão não só no contexto moçambicano, como também no brasileiro.

- Incentivo à cultura moçambicana na Universidade:

Ainda na primeira semana de nossa estadia em Moçambique, além de uma imersão no contexto da ciência e pesquisa como mencionado, pudemos participar de um festival cultural e gastronômico na própria 
UEM (Figuras 4 a 7). Com o festival conseguimos conhecer diversas características culturais, como trajes típicos, vestimentas, instrumentos musicais, artesanato, dentre outros, e também gastronômicos de quase todas as províncias do país.

Figura 4. Festival Cultural Universitário. Foto Amilton Luiz Novaes (2016).

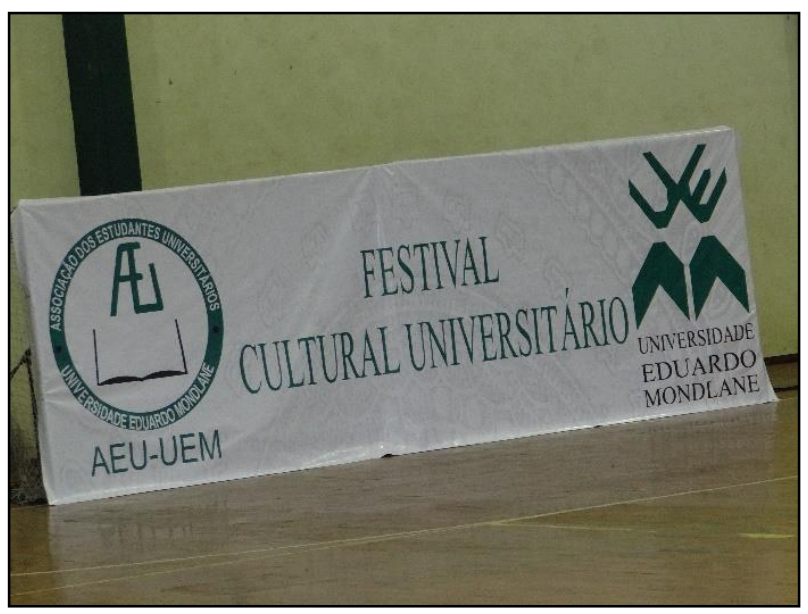

Figura 5. Mascote da Universidade Eduardo Mondlane. Foto Amilton Luiz Novaes (2016).

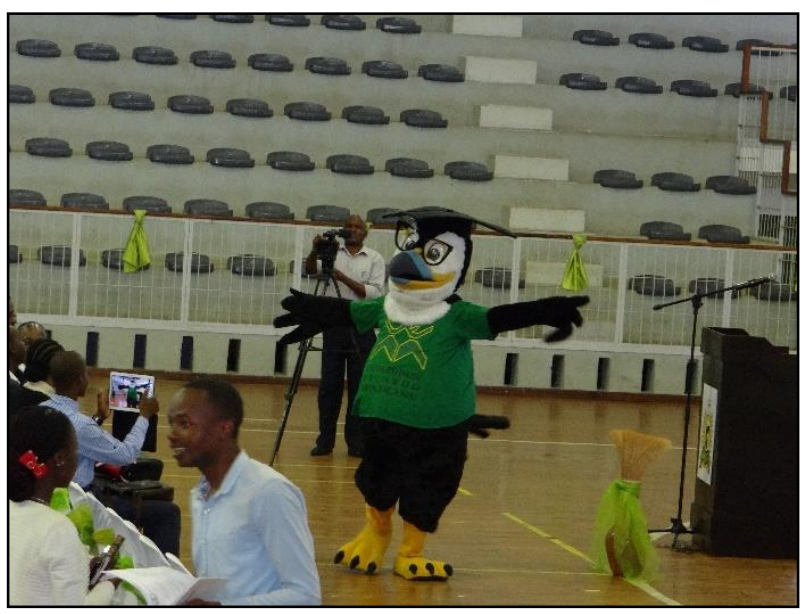

O evento tinha a participação efetiva dos alunos, tanto na organização, que era em parceria entre a universidade e a Associação dos Estudantes Universitários da UEM, quanto na execução, pois eram os próprios alunos de cada província que elaboravam os pratos típicos, faziam as danças, etc. Além de que havia uma competição gastronômica entre cada uma das barracas de cada província. Aqueles que estivessem mais caracterizados, e apresentassem os melhores pratos, com a barraca melhor caracterizada de acordo com elementos de cada região, seriam escolhidos vencedores (Figuras 6 e 7). Devemos destacar que fomos 
privilegiados por termos tal oportunidade de participar e presenciar o evento. Além de poder experimentar diversos pratos típicos das mais variadas províncias de Moçambique.

Entretanto, não são apenas esses os aspectos relativos à cultura que temos como destaque, por isso, iremos abordar no tópico seguinte outros pontos que consideramos de grande relevância dentre os elementos identitários da cultura moçambicana.

Figura 6. Barracas representando suas províncias e servindo um de seus pratos típicos. Fotos de Amilton Luiz Novaes (2016).

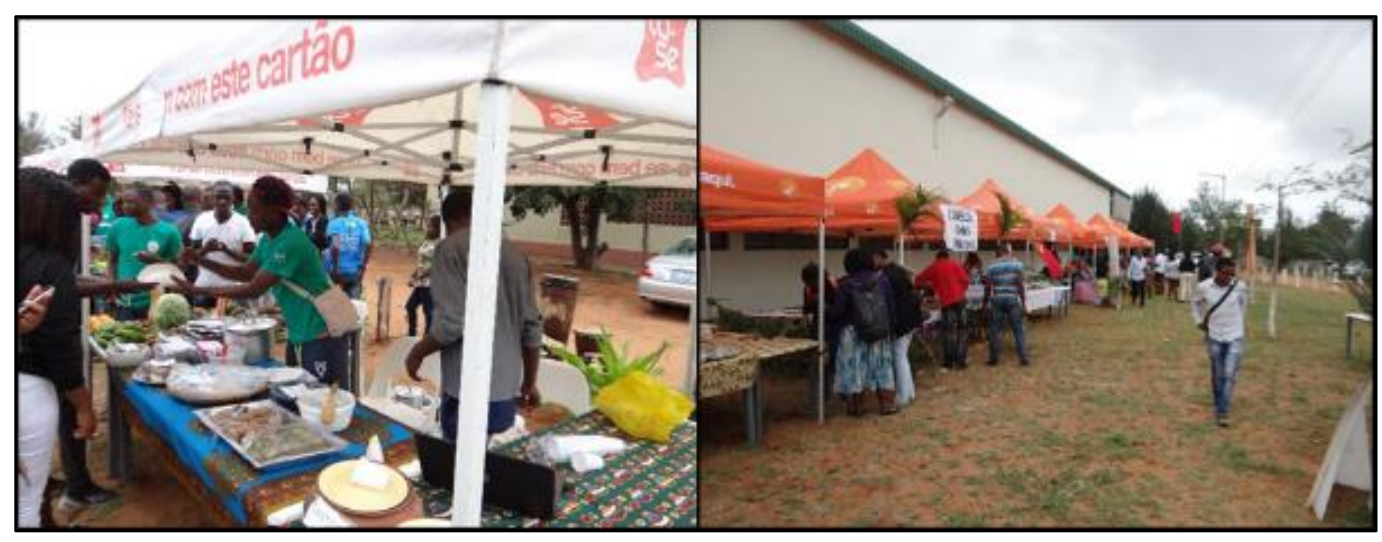

Figura 7: Barracas de diversas províncias durante o Festival Cultural Universitário. Fotos de Amilton Luiz Novaes (2016).

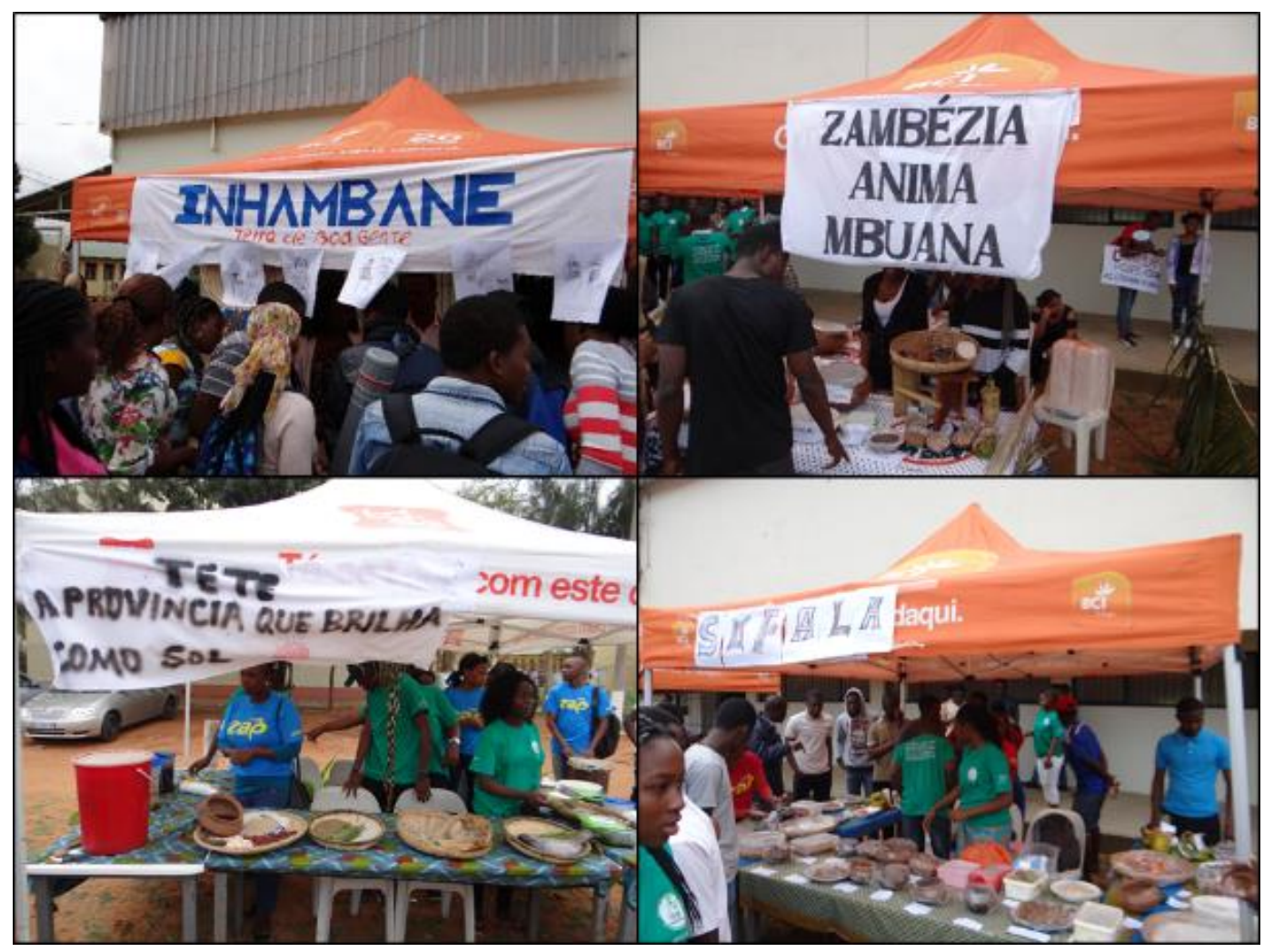




\section{Aspectos Culturais}

Em geral, percebemos o avanço da globalização também quando analisamos as características culturais e gastronômicas, isto pois, em ambos os casos as culturas dominantes acabam por se sobrepor (e subjugar) as culturas locais. Todavia, foi possível observar traços bem marcantes, e que a população mantém vivos seus costumes, saberes, gastronomia e outros referenciais identitários. Identificamos também aspectos globalizados da gastronomia, tal como a rede de fast food $\mathrm{KFC}^{5}$.

Figura 8. Fast food do KFC. Fotos de Karoline

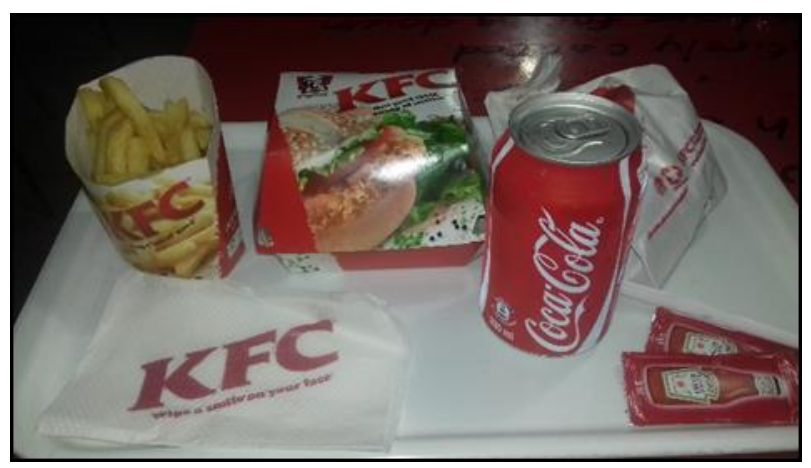

Outro referencial de destaque que observamos diz respeito as roupas e vestimentas usadas pelos moçambicanos. Ademais, as formas como eles se vestem diz muito sobre seus referenciais identitários. E ao falarmos das vestimentas moçambicanas, a primeira referência que nos fica evidente é o uso das chamadas Kapulanas, que de alguma forma está presente em quase todas as roupas e vestuários produzidos no país. Para além de roupas, que já é aproveitada de distintas maneiras, a kapulana é utilizada de forma decorativa, como arte (pois pode ser emoldurada e posta em exibição), e até nos acessórios que podem ser bolsas, bijuterias, lenços, carteiras, etc., ou outros usos domésticos.

Figura 9. Exemplos de kapulanas. Fotos de Karoline Batista Gonçalves (2016).

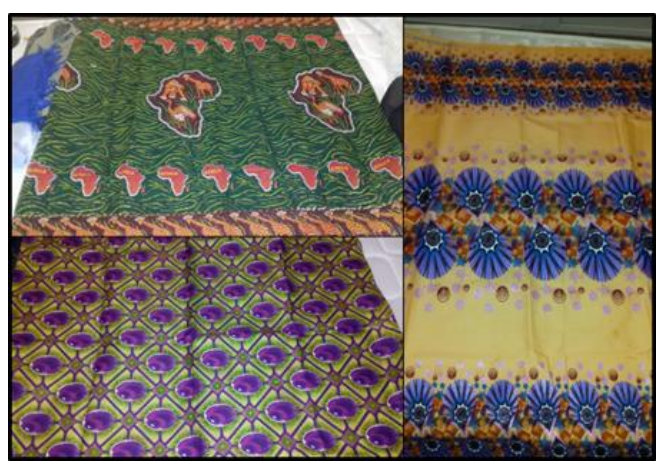

${ }^{5}$ Rede de fast food Kentucky Fried Chicken (KFC) de origem estadunidense, com sede em Louisville, Kentucky, que tem como base de seus pratos o frango frito. 
Em sua maioria, as kapulanas, possuem estampas de desenhos geométricos que acabam resultando em uma interessante combinação de cores e formas. Além de ser utilizada para a produção da vestimenta tradicional moçambicana, a kapulana também traz impressa em alguns modelos as principais e relevantes mudanças na sociedade, às preferências políticas, objetos e costumes de algumas comunidades africanas dentre outras características. A kapulana é um tecido também utilizado em outros países do continente africano, cuja matéria-prima provém do algodão e da lã, mas o destaque mesmo fica para Moçambique.

Figura 10. Bolsa e mochilas de kapulanas na feira de artesanato em Maputo. Fotos de Amilton Luiz Novaes (2016).

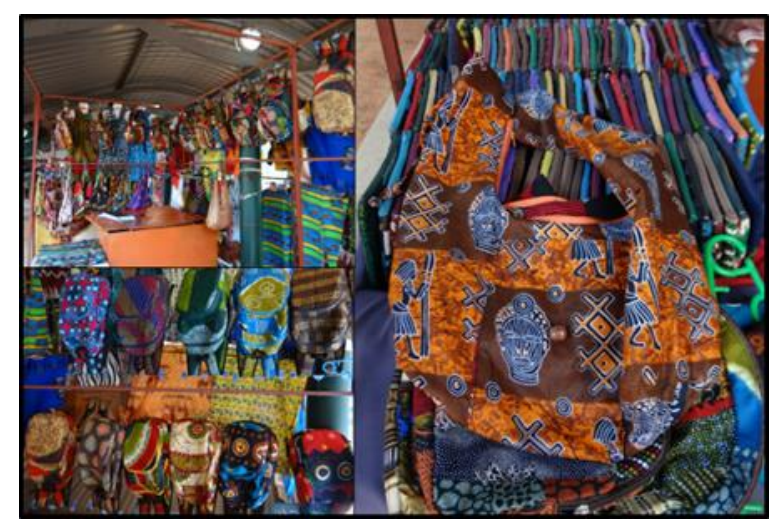

A maneira como as mulheres moçambicanas as amarram para dar formato as suas vestimentas, é única e particular, que vai perdurando por várias gerações. Nesse sentido, podemos afirmar que a kapulana é um referencial identitário do povo moçambicano, pois, é utilizada por homens e mulheres (mas em especial às mulheres). É comum observarmos toda uma família usando vestes de um mesmo modelo de kapulana.

Figura 11. Mulheres usando kapulana (superior esq. e à dir.) e uma família moçambicana (inferior esq., detalhe para o casal usando a mesma kapulana). Fotos de Karoline Batista Gonçalves (2016).

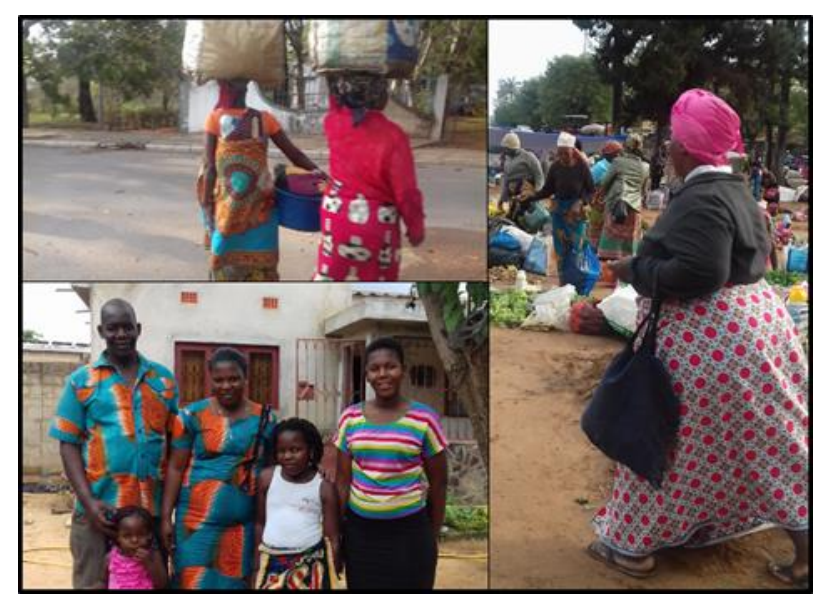


Durante o período que estivemos em Maputo, notamos que entre as pessoas que se dedicavam a desenhar e costurar os modelos de roupas com kapulanas não havia apenas mulheres, mas havia uma quantidade significativa de homens que trabalhavam na produção e costura de roupas (os homens eram a maioria nessa atividade).

Com relação às roupas que são utilizadas no cotidiano para ir ao trabalho ou a escola, a universidade o uso de um traje mais social é frequente. Tanto homens quanto mulheres optam por utilizar trajes mais refinados, como calça social, ternos, gravatas, dentre outros. É interessante destacar que as mulheres sempre usam roupas com uma postura mais séria sem muita exposição.

Algo que nos chamou a atenção além das características mencionadas anteriormente, é que os moçambicanos em sua maioria são muito prestativos e receptivos, e sempre levam consigo os referenciais que representam sua nacionalidade e identidade. Aliás, foi possível identificar a existência de uma diversidade cultural imensa, pois sujeitos de diferentes grupos étnicos, com usos e costumes distintos convivem e estabelecem relações que resultam em uma mescla, e muitas vezes acabam sofrendo influências de fatores políticos e religiosos.

Figura 12. Mesquita no centro histórico de Maputo. Fotos de Amilton Luiz Novaes (2016).

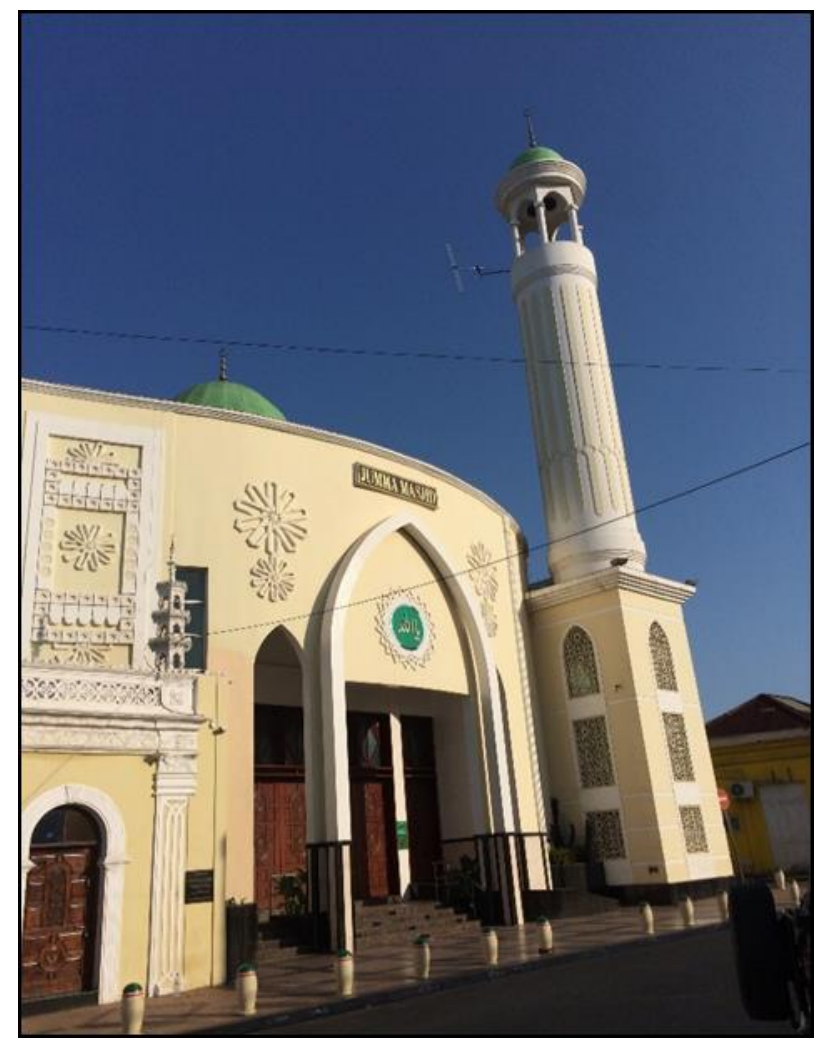


Dentre as diversas características apresentadas percebemos também que Moçambique está ligado ao Oriente Médio e a Índia, pois em Maputo, podemos identificar alguns aspectos de influência dessas regiões nos referenciais culturais-identitário que englobam desde a religião, as vestimentas e a culinária. Mas cabe destacar que o Brasil tem exercido grande influência nas questões culturais locais, principalmente por meio da rádio e televisão ligados à Rede Record e no aspecto religioso por meio da Igreja Universal. Pudemos observar que a igreja evangélica tem se tornado predominante em Moçambique, não somente pelo grande avanço e rápida ampliação de unidades da igreja Universal espalhada pelo país, mas também pela presença de outras igrejas evangélicas.

Figura 13. Templos da Igreja Universal em Maputo (à esq, e inferior dir.) e em Marracuene. Fotos de Amilton Luiz Novaes (2016).

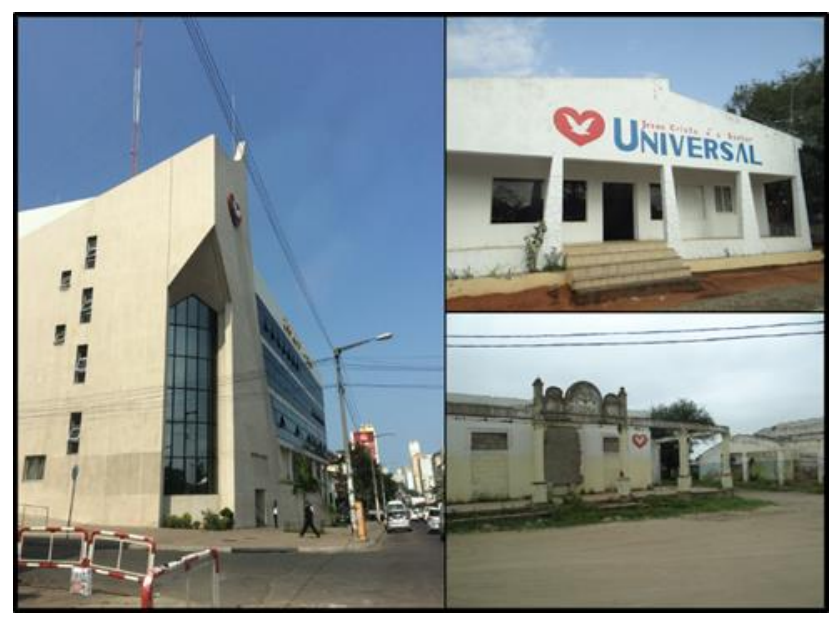

A figura do curandeiro possui uma grande importância na sociedade moçambicana, principalmente entre a população mais carente, que em algumas situações de doenças ou outros problemas, estando desprovidos de recursos financeiros recorrem a eles em busca de uma solução. O curandeiro, na maioria das vezes, vive nas próprias comunidades e sua fama vai sendo construída, à medida que seus pacientes obtêm resultados positivos.

Em relação à música foi possível perceber que ela está presente no cotidiano do moçambicano e aparece com distintos propósitos que englobam desde expressões religiosas, atos comemorativos até cerimonias tradicionais. No período em que ficamos em Maputo notamos que existem vários centros culturais estrangeiros que promovem oficinas no intuito de desenvolver atividades culturais para retratar tanto alguns países como para valorizar a cultura moçambicana. No caso da música, devido a influência da Rede Record, 
ouvimos algumas músicas brasileiras, além de que as novelas e demais produções brasileiras dessa emissora são reproduzidas em território moçambicano.

Contudo, é preciso ressaltar que a riqueza cultural encontrada em Moçambique é única e distinta. Ficou evidente que o sentimento e o orgulho de ser moçambicano faz parte da identidade das pessoas que lá vivem. Por mais que o país tenha passado por muitas dificuldades nos últimos anos em busca de uma estabilidade política.

\title{
Aspectos Econômicos
}

A partir do momento que estabelecemos relações com outra identidade tornam-se evidentes as diferenças, pois o território nos proporciona o encontro e o desencontro, ou seja, se torna o espaço em que nos deparamos com o outro. Um território pode abarcar a vivência de múltiplas territorialidades, ou seja, vários referenciais identitário podem estar presentes nas relações que são estabelecidas nesse território. Partindo desse pressuposto, nos pautaremos a observar alguns detalhes das vivências moçambicanas e das múltiplas maneiras como a territorialidade se expressa.

Sendo assim, a primeira característica que podemos apontar diz respeito ao uso da terra, seja do ponto de vista econômico, ou mesma da função social da terra. Diferente de outros países (tal como o Brasil) em Moçambique não existe a propriedade privada da terra, pois está pertence ao Estado. Convém mencionar que isso deriva de um curto período de tempo em que o estado moçambicano se considerava socialista. Mais ainda, vale destacar que isso se deve principalmente no momento de independência, ou seja, quando deixam de ser colônia de Portugal. Sendo assim, toda propriedade era pertencente aos portugueses, então a forma encontrada pela gestão da república independente de Moçambique foi adotar o Estado como proprietário que concede ao seu povo o Direito de Uso e Aproveitamento de Terra (DUAT).

\begin{abstract}
Na República de Moçambique a terra é propriedade do Estado e não pode ser vendida, ou por qualquer outra forma, alienada, hipotecada ou penhorada. Como meio universal de criação da riqueza e do bemestar social, o uso e aproveitamento da terra é direito de todo povo moçambicano. As condições de uso e aproveitamento da terra são determinadas pelo Estado. O direito de uso e aproveitamento da terra é conferido às pessoas singulares ou colectivas tendo em conta o seu fim social (MOÇAMBIQUE, 2015, p.01).
\end{abstract}

No entanto, diferentes tipos de uso são direcionados a ela, tais como as maxambas ${ }^{6}$, que ao menos em Maputo e suas proximidades, é comum encontrá-las espalhadas pela cidade, mesmo em terras públicas. Como

\footnotetext{
${ }^{6}$ Os autores desse texto também produziram um filme, um curto documentário, denominado "As Maxambas" em que apresenta essa relação do povo moçambicano com a terra, o uso delas e sua produção. O filme encontra-se disponível no link:

https://youtu.be/2VupchQDrNc.
} 
é o caso de diversas maxambas localizadas no interior do campus universitário da UEM. As maxambas são pequenos cultivos em uma parcela de terra que pode variar sua extensão, onde são cultivados frutas, legumes e verduras que podem servir tanto para o próprio sustento, quanto para a comercialização.

A Figura 14 é apresenta um exemplo de maxamba desenvolvida em um espaço público, localizado dentro da Universidade Eduardo Mondlane, cedido aos funcionários para que possam cultivar suas maxambas em "espaços vazios". As maxambas estão presentes nas cidades, onde os moçambicanos agregam outro uso para a terra que não é apenas construir, mas produzir alimentos. As relações que os moçambicanos estabelecem com suas maxambas podem ser caracterizadas como aquelas que eles constituem com o seu espaço de vida através do cultivo, do cuidado e com os sujeitos entre si, pois os produtos desses cultivos podem tanto ser utilizados pela família para prover sua necessidade, como serem comercializados na própria vizinhança, ou em outras partes da cidade e sendo até presenteáveis ou trocados.

Figura 14. Maxambas - superior esq. maxamba no campus da UEM, inferior esq. maxamba ao lado de uma avenida em Maputo e dir. autores em trabalho de campo em maxamba no campus da UEM. Fotos de Karoline Batista Gonçalves (2016) (sup. esq.), Amilton Luiz Novaes (2016) (inf. esq) e Edvaldo Cesar Moretti (2016) (dir.).

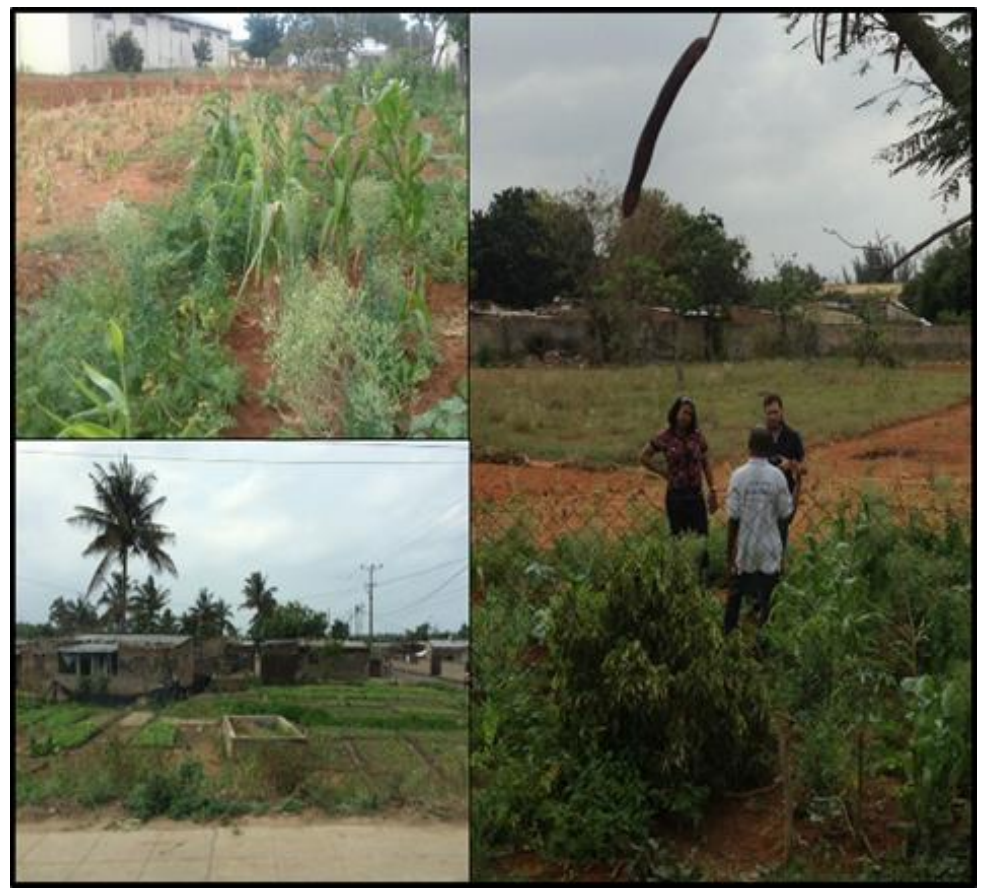

Em alguns casos os produtos oriundos desses cultivos são vendidos em pequenas bancas que eles montam nas ruas de maiores movimentos, ou nas feiras localizadas tanto nas cidades quanto nos distritos. $\mathrm{E}$ essas feiras em algumas localidades acontecem de maneira bem tradicional, sem muita estrutura diferente daquelas encontradas nos mercados municipais. 
Figura 15. Exemplos de comercialização dos produtos das maxamba. Fotos à esquerda de Karoline Batista Gonçalves (2016) e à direita de Amilton Luiz Novaes (2016).

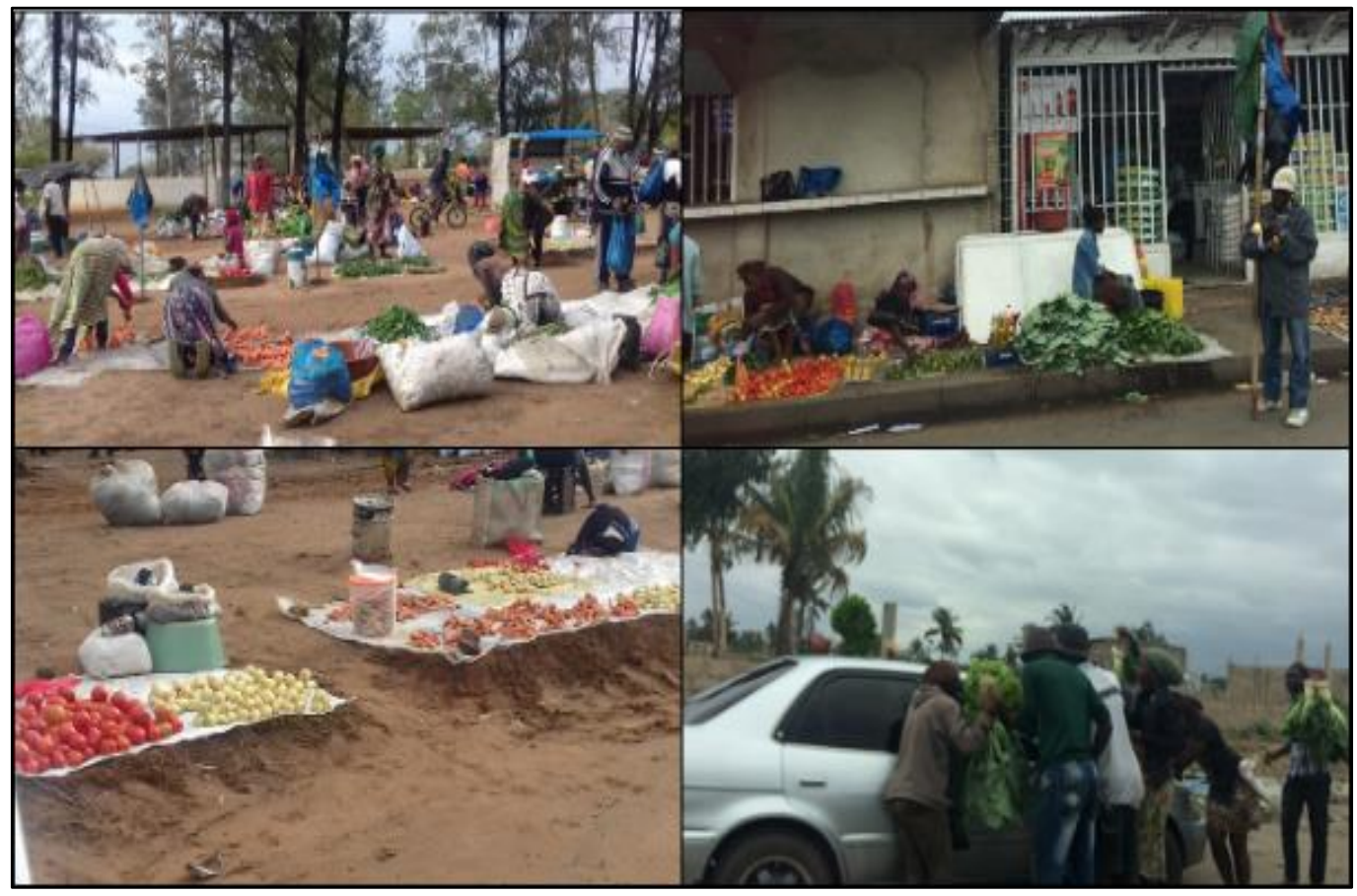

Na Figura 15 as fotos superior e inferior à esquerda, retratam uma feira tradicional que acontece aos sábados no distrito de Marracuene, próximo às margens de um rio. Na foto superior à direita é exemplo de uma das diversas bancas localizadas nas calçadas, por toda a cidade de Maputo (inclusive na região do centro da cidade), para a comercialização de diversos produtos. E a foto inferior à direita demonstra outra forma de comercialização, na qual um batalhão de pessoas abordam os carros que param para comprar produtos das maxambas dos comerciantes que ficam à beira das ruas apresentando seus produtos.

É interessante destacar que, pelo menos nas feiras que visitamos em Maputo e nas imediações, foi possível constatar que uma parte considerável de pessoas que trabalham nessa atividade são mulheres (como pode ser observado em diversas imagens). E em alguns casos elas são responsáveis desde o cultivo em suas maxambas até a comercialização dos produtos. E também são elas as responsáveis pelo transporte (de forma bastante peculiar) desses (e outros) produtos, como pode ser observado na foto superior à esquerda da Figura 12. Frequentemente, em alguns bairros da cidade encontrávamos mulheres carregando objetos pesados em sua cabeça, acomodamos com o auxílio de um tecido (geralmente kapulana).

A mulher moçambicana se destaca pela sua força e habilidade em executar alguns trabalhos, que em outros locais do mundo seriam executados apenas por homens. Essas mulheres em alguns casos acabam se dedicando a comercializar produtos que exigem um esforço físico maior, como, por exemplo, o carvão. Em 
vários locais das cidades é possível encontrar mulheres que preparam e comercializam esse produto. A Figura 16 retrata um grupo de mulheres que estavam trabalhando na preparação do carvão de maneira tradicional.

Figura 16. Mulheres moçambicanas preparando o carvão para venda. Foto de Karoline Batista Gonçalves (2016).

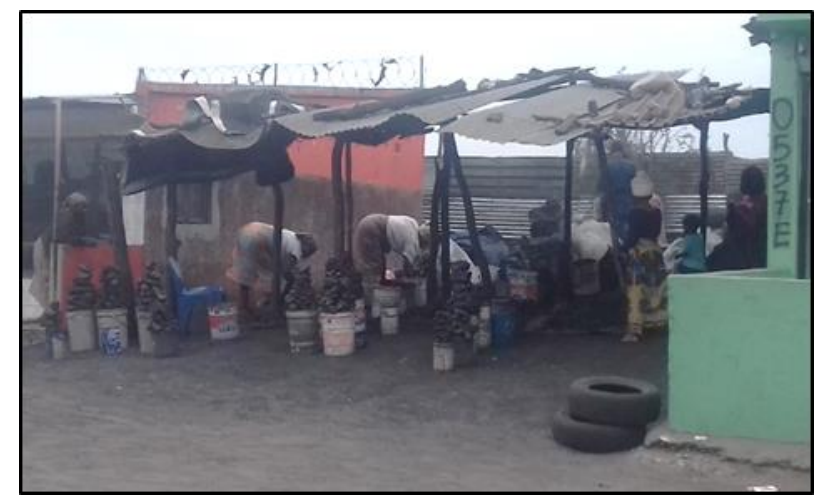

Outra atividade que está muito presente na realidade moçambicana é o artesanato, e foi possível observarmos na cidade de Maputo, em diversos locais, venda e confecção de diversos produtos de artesanatos. Os objetos são variados, desde esculturas e outros artefatos de madeiras ou pedra, os batiks, que são pinturas em tela, multicoloridos, que retratam valores da sociedade moçambicana, dentre outras coisas, além de roupas e acessórios produzidos a partir da kapulana conforme já mencionado.

Figura 17. Observando os batiks em feira de artesanato de Maputo. Foto de Edvaldo Cesar

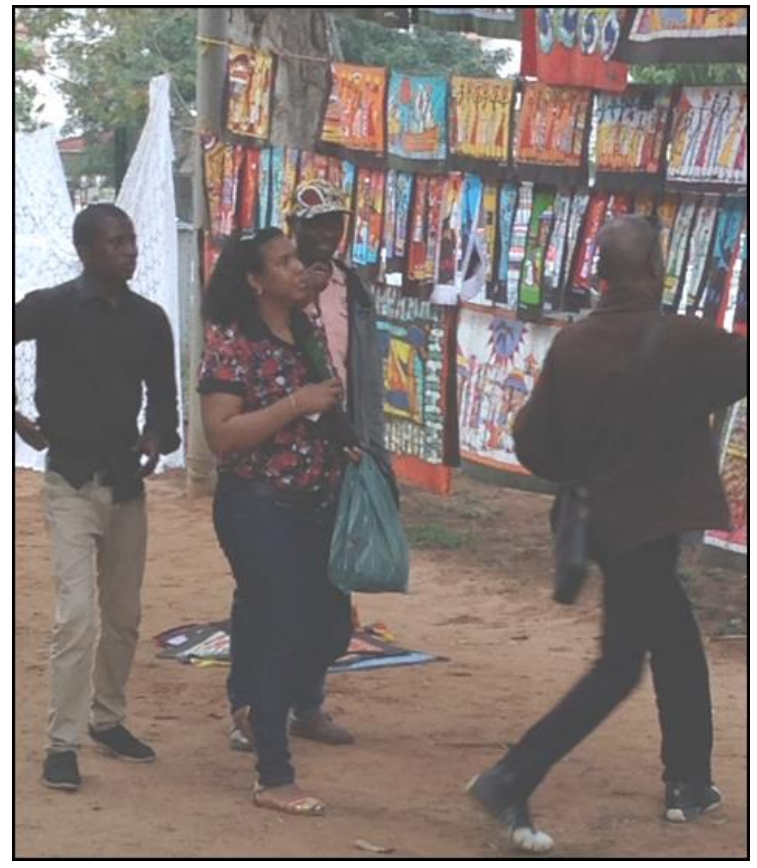


O artesanato moçambicano estabelece múltiplas conexões, pois permite que a arte e o referencial identitário sejam internacionalizados. Durante nossa estadia no país observamos que tanto nas ruas, através dos vendedores autônomos, nas lojas, nos mercados e feiras encontramos uma infinidade de opções e de preços.

Em Maputo, e alguns distritos, observamos que outra atividade que contribui para o trabalho, geração de renda, movimenta a economia e dá o sustento de muitas famílias, é a pesca. Nessas regiões a atividade é desenvolvida devido à presença da costa marítima do Oceano Índico, e a uma infinidade de espécies marítimas. A pesca é uma atividade importante para o país, pois, além de ser uma fonte de alimentação, gera empregos, fornece matéria-prima para as indústrias de conservas, farinhas e rações e acaba se tornando uma porta para ao comércio exterior. É importante salientar que a pesca artesanal tem um destaque no país sendo caracterizada pela utilização de técnicas rudimentares e o uso de pequenas embarcações, uma realidade presente principalmente nos distritos vizinhos à Maputo.

Figura 18. Pesca artesanal na praia de Macaneta no distrito de Marracuene. Foto de Karoline Batista Gonçalves (2016).

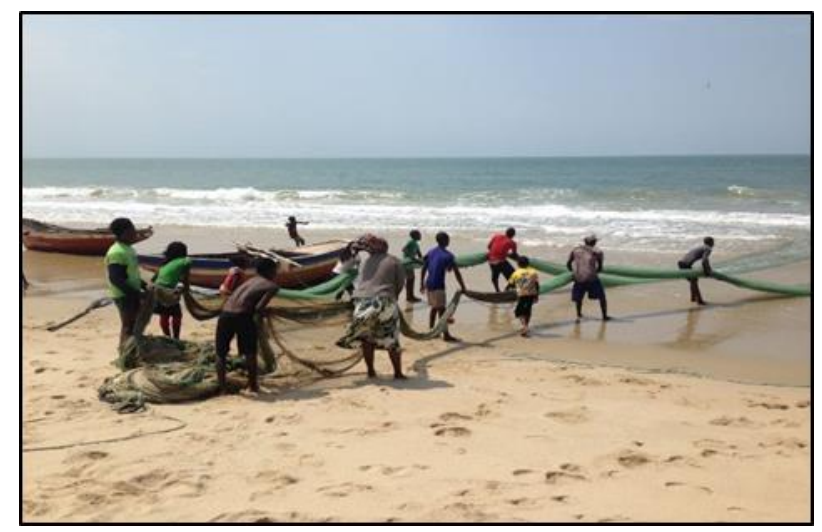

Outra atividade frequentemente encontrada nas ruas da cidade de Maputo, é o comércio informal. Mas não estamos falando de feiras para comercialização das produções das maxambas, nem de artesanatos. É o comércio informal de produtos industrializados, dos mais variados tipos, desde calçados, roupas, tecidos (kapulanas por exemplo), bebidas, eletrônicos, etc., ou mesmo semi industrializados, como pães, badjias (um tipo de salgado frito típico do local) e outros produtos alimentícios. Em alguns casos são estruturas que imitam, ou procurar dar um caráter de comércio formal. É possível perceber que para a economia local o mercado de trabalho informal é bastante significativo, e demonstra uma (triste) característica dessa sociedade (revelamos que temos receio de o Brasil avançar nesse mesmo sentido com as propostas de reformas trabalhistas do atual governo). 
Figura 19. Comércio de produtos industrializados pelas ruas de Maputo. Fotos de Amilton Luiz Novaes (2016).

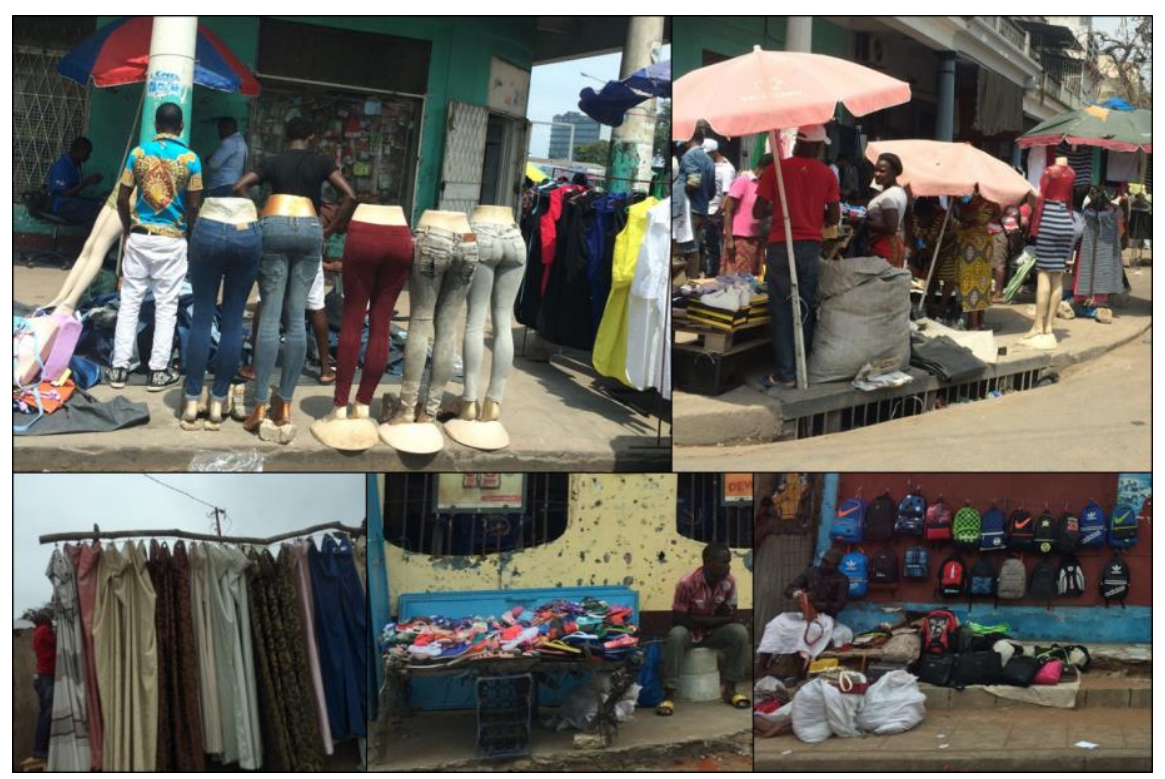

Notamos também que o avanço do capital chinês é bastante significativo e intenso. Foi possível perceber que essa inserção do capital chinês ocorre de diversas formas na estrutura econômica do país. Observamos a presença de empresas e mão de obra chinesas, por exemplo, na construção civil, construção de infraestrutura rodoviária (estradas, pontes, etc.), instalação de vigilância eletrônica (instalação de câmeras de monitoramento nas vias públicas), indústrias, hotéis, institutos de pesquisa, etc. Estas em se tratando de Maputo e seu entorno, nas demais províncias outras atividades econômicas poderiam ter destaque. Percebemos ao longo das estradas, nas regiões próximas à Maputo, diversas empresas que possuíam em sua entrada placas com dizeres escritos em idioma chinês.

Figura 20. Obras prontas e em execução com o capital e empresas chinesas. Fotos de Amilton Luiz Novaes (2016).

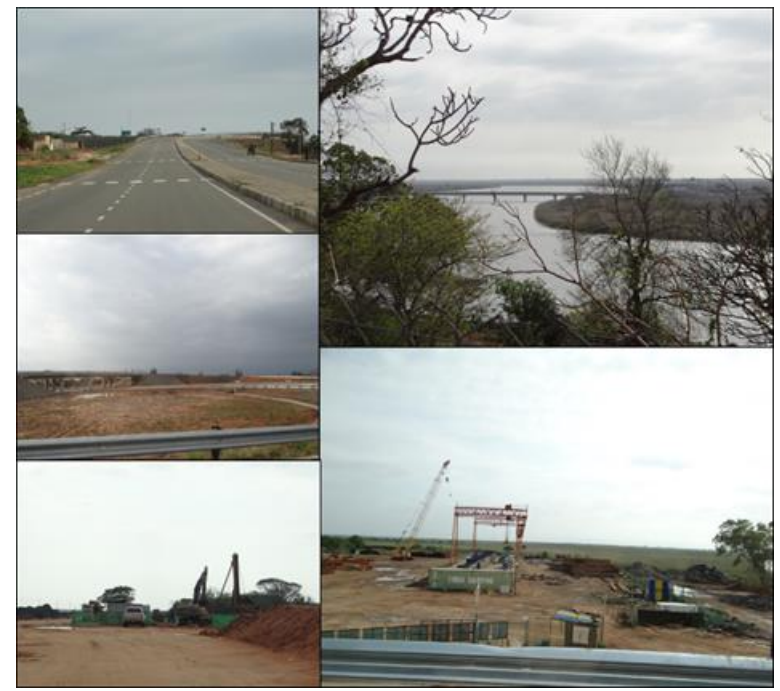


Figura 21. Investimentos chineses - à esq. instituto de pesquisa chinês (no detalhe, placa de identificação do instituto, inferior esq.) e à dir. hotel chinês. Fotos de Amilton Luiz Novaes (2016).

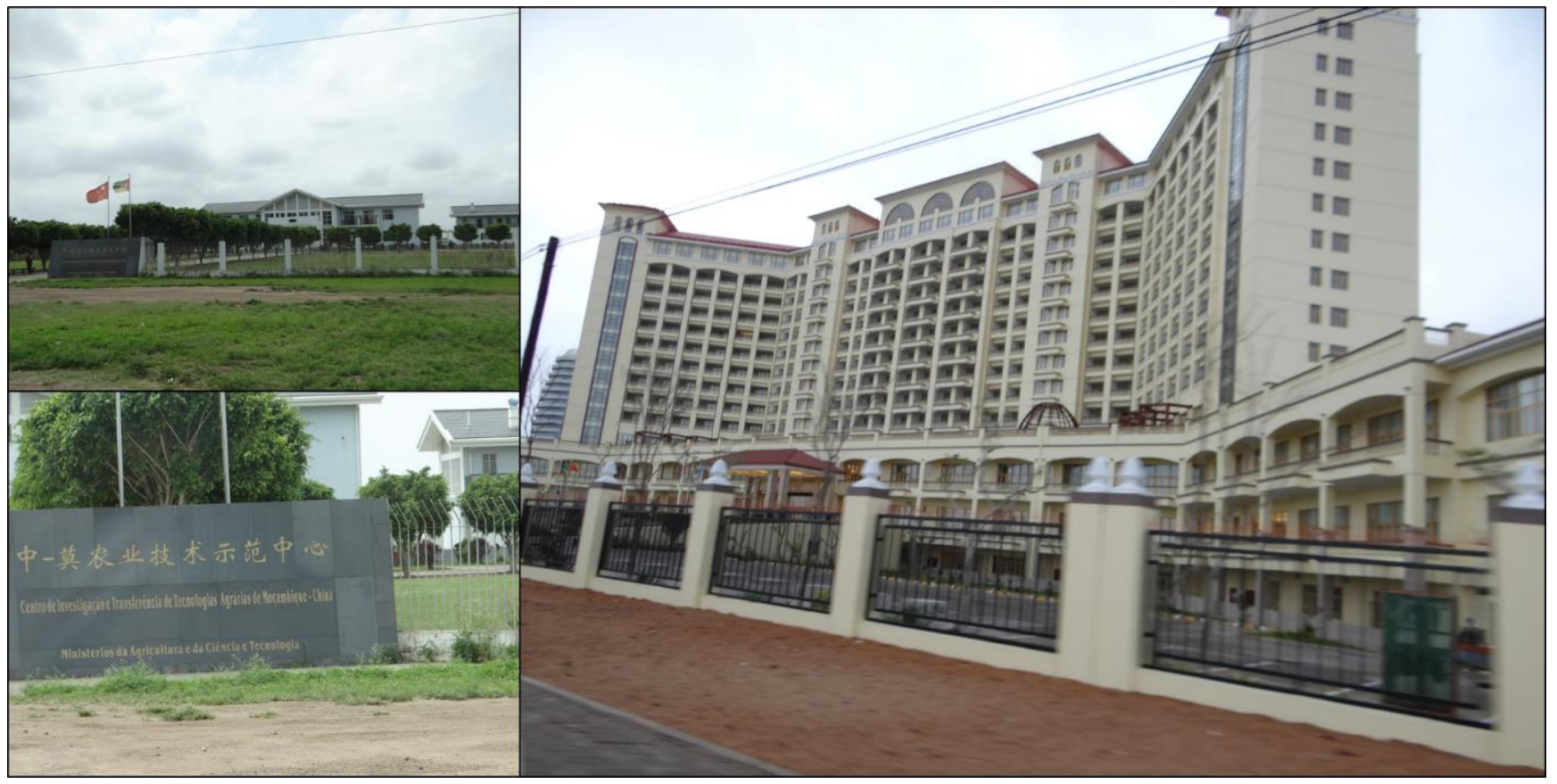

Turismo em Maputo

No que diz respeito ao turismo em Moçambique, nos pautaremos em relatar o que foi possível observar partindo de nossas vivências e experiências na Província de Maputo e seus distritos, pois não temos como apresentar um panorama geral do país, haja vista que nossa estadia limitou-se a esta província e alguns de seus distritos. Inicialmente, o que nos chamou nossa atenção foi a área da zona costeira do Índico, mais especificadamente a região da "orla da costa do sol", local que apresenta uma praia muito atraente, mas pouco utilizada para banhos, largas avenidas e um enorme calçadão propício para caminhada e contemplação da paisagem.

Nessa área foi possível notar a instalação de grandes e luxuosos hotéis, oriundos de capital estrangeiro, casinos e restaurantes renomados, que visando conciliar uma bela paisagem com conforto e ótimas opções, acabaram propiciando uma nova estrutura para a região como podemos observar na Figura 22. 
Figura 22. Imagens da Orla Costa do Sol. Fotos de Karoline Batista Gonçalves (2016).

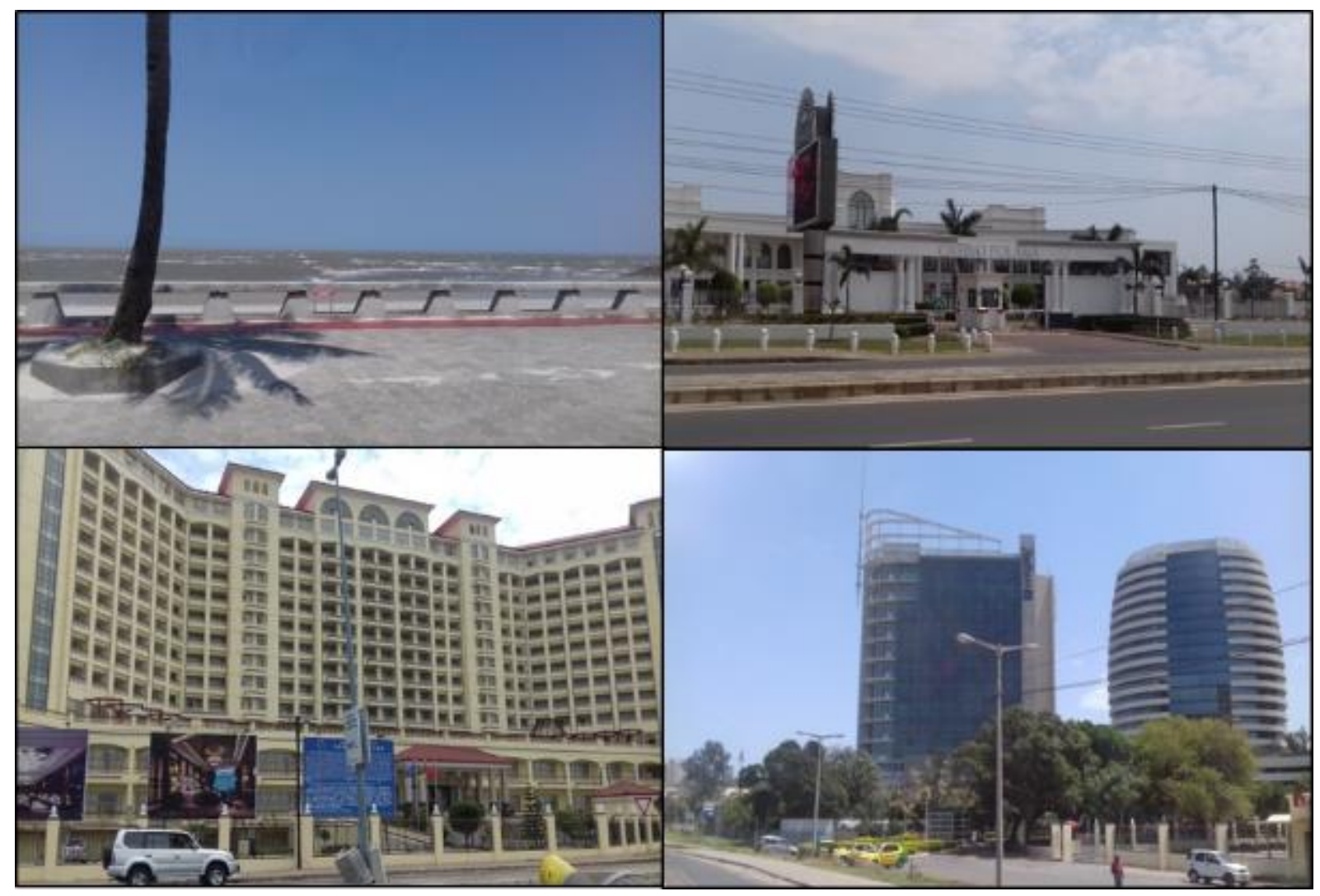

Além das opções luxuosas, podemos encontrar também o "Mercado do Peixe" uma estrutura tradicional e "mais popular", que antes se encontrava em outro ponto dessa mesma região, todavia com certa precariedade e não se localizava de frente ao mar. A estrutura atual do Mercado do Peixe foi construída recentemente, e além de ser um lugar para a comercialização de peixes e frutos do mar frescos, ele possui pequenos restaurantes e comércios que oferecem refeições, cujo prato principal trata-se de peixes, mariscos e crustáceos.

Existem diversos estabelecimentos, em vários pontos da cidade, onde o turista pode encontrar produtos típicos, artesanatos e souvenires. Além das lojas localizadas na região da Baixa da cidade, podemos elencar: a feira da Praça 25 de julho que ocorre aos sábados, a Feira de Artesanato, Flores e Gastronomia de MaputoFEIMA e o Mercado Central que possui uma infinidade de produtos e variedades. Outros lugares que visitamos, durante nossa estádia, considerados grandes atrativos turísticos são: a casa de ferro, a fortaleza de Nossa Senhora da Conceição que atualmente transformou-se no museu militar, a estação Central dos Caminhos de Ferro e o Museu de História Natural.

Em relação a outros locais com vocação turística, conhecemos a Praia de Macaneta, localizado em Marracuene, que possui uma paisagem incrível, no entanto, o acesso a essa praia até o momento em que 
estávamos no país estava restrito, devido a instalação de cancelas que controlavam e limitavam a entrada a praia, pois era necessária pagar uma taxa, com o argumento de que esta seria uma cobrança do estacionamento. Fato que para muitos moçambicanos se tornou um impedimento para visitação.

Além da Praia de Macaneta, conhecemos a Vila de Naamacha, que possui uma cascata famosa por atrair muitos turistas. No entanto, ao chegarmos no local para nossa surpresa o nível de água da cascata havia baixado tanto, estando completamente seca, que já não foi possível contemplar esse atrativo. Local que por muitos anos foi uma referência turística para a região. Foi a partir dessa experiência que entendemos que para o turismo em Moçambique desenvolver-se é necessário adotar políticas que possam desenvolver, ou mesmo priorizar essa atividade, visando proporcionar estrutura adequada e também mantê-la. Nesse ínterim, ouvimos relatos contundentes de que o país poderia oferecer mais o turismo natural, com visitas às reservas ou áreas de proteção ambiental, tal como ocorre no país vizinho, África do Sul, no famoso Kruger Park.

Resumidamente, o que ficou claro durante nossas vivências no país é que o turismo de sol e praia é o que tem grande destaque em Maputo e região, principalmente para estrangeiros, e existe de fato um potencial para crescimento. Contudo, é necessário investir em infraestrutura e na qualidade dos serviços prestados. Nos últimos anos o turismo dessa região tem sido voltado mais para um viés regional, no qual tem atraído turistas da África do Sul, Zimbabwe e Suazilândia. E recentemente, atraídos pelos investimentos e obras de infraestrutura, aumentou o número de chineses que escolhem o país como destino turístico.

Enfim, percebemos que o turismo em Maputo e seus distritos, vive uma fase de desenvolvimento, no qual necessita uma reestruturação em alguns aspectos, respeitando as necessidades locais, bem como capacitando os diversos atores envolvidos nessa atividade. Além disso, grande parte das transformações que estão ocorrendo na cidade são direcionadas a atrair mais turistas, pois para que essa atividade possa crescer e se estruturar no país ela tem que atender aos requisitos do turista atual, que busca além de lugares exuberantes e lazer, comodidade.

\section{CONSIDERAÇÕES FINAIS}

A vivência que tivemos em Moçambique nos proporcionou identificar múltiplos referenciais, nos deparamos com a figura do outro, neste caso o moçambicano, que possui características identitária distintas, e durante essa experiência fomos alçados ao movimento de (re)definição de "nós" e dos "outros". Pois, o nosso olhar sobre a organização, as tradições, os costumes, o modo de vida nos permitiu elaborar um novo olhar sobre a realidade moçambicana que antes estava carregada de contestações, afirmações e relativizações. 
O território moçambicano possui uma rica diversidade, que pode estar ligada a religião, política, costumes e tradições. Nesse sentido, podemos evidenciar a territorialidade moçambicana como relações cristalizadas entre os sujeitos, e destes com o seu lugar de vida. E esse sentimento de pertencimento, está presente em situações e práticas do dia-a-dia, que foram relatadas anteriormente, tais como a língua, a forma de se vestir, a comida, o artesanato dentre outras características.

Ao observarmos a cidade de Maputo percebemos e compreendemos o território como um produto e condição da vida em sociedade e em natureza, onde ocorrem constantes mudanças e transformações, continuidades e descontinuidades que podem ser materiais, desde as grandes construções e obras de infraestrutura, até simbólicas, como a influência na identidade.

Ficou evidente que os moçambicanos interagem com o seu território de maneira cultural, política e econômica própria, isto é, eles agregam características que fazem parte de seus costumes, das trajetórias de vida e de seus antepassados e esses elementos são valorizados e utilizados para afirmar sua identidade. Dessa forma, percebemos que a identidade moçambicana está pautada nos referenciais que estão presentes no território, e conforme, a intensidade das relações acaba se adaptando as realidades vivenciadas.

Consideramos que durante o intercâmbio, a proximidade, o contato e o auxílio oferecido pela Universidade Eduardo Mondlane contribuíram para nos situarmos, a respeito de como outros países tem discutido as principais categorias da geografia, assim como identificar algumas particularidades do território moçambicano. Conhecer um país da África que tem como idioma oficial o português, foi uma experiência enriquecedora, além de criar outra perspectiva acerca da realidade moçambicana, onde nacionais e estrangeiros de diferentes culturas, identidades, religiões e concepções de mundo distintas dividem o mesmo território.

\section{REFERÊNCIAS}

MOÇAMBIQUE. Direito do Uso e Aproveitamento de Terra. 2015. Portal do Governo de Moçambique. Disponível em: http://www.portaldogoverno.gov.mz/por/Cidadao/Informacao/Direito-do-Uso-eAproveitamento-de-Terra. Acesso em: 11 de novembro de 2016.

SADER, Emir. África, o continente de todos. Carta Maior Blog do Emir. Disponível em:<http://www.cartamaior.com.br/?/Blog/Blogdo-Emir/africa-o-continente-de-todos/2/23676> Acesso em: 26 de fevereiro de 2017.

SAQUET, Marcos Aurélio. Estudos territoriais: os conceitos de território e territorialidade como orientações para uma pesquisa científica. In: FRAGA, Nilson Cesar (Org.). Territórios e Fronteiras: (Re) Arranjos e Perspectivas. Florianópolis: Insular, 2011.

SAQUET, Marcos Aurélio. Por uma Abordagem Territorial. In: SAQUET, Marcos Aurélio; SPOSITO, Eliseu Savério. Territórios e territorialidades: teorias, processos e conflitos. 2a ed. Rio de Janeiro: Consequência Editora, 2015.

TIMBANE, Alexandre António. Que português se fala em Moçambique? Uma análise sociolinguística da variedade em uso. Vocábulo: Revista de Letras e Linguagens Midiáticas, vol. 7, UFSC, 2014. 